\title{
A Lower Dose of Magnesium Sulphate for Control of Convulsion in Eclamptic Women of Bangladesh
}

\author{
SULTANA N ${ }^{1}$, BEGUM K ${ }^{2}$, BEGUM A ${ }^{3}$ AKHTER $U^{4}$
}

\begin{abstract}
:
Eclampsia, a life threatening complication of pregnancy. It is one of the important cause of maternal mortality of Bangladesh. Eclamptic seizure can effectively controlled by use of magnesium sulphate. A prospective randomized case control study was conducted at eclampsia ward of Dhaka Medical College Hospital for one year from June 2007 to May 2008.

Objective: To find out whether only 8gm of magnesium sulphate heptahydrate (Nalepsin) as a single loading dose is sufficient to control eclamptic convulsion and also to compare the efficacy between $8 \mathrm{gm} \& 10 \mathrm{gm}$ of $\mathrm{MgSO}_{4}$ used to control convulsion.

Methodology: A random selection was done by lottery of those antepartum and intrapartum cases who fulfill the selection criteria. Hundred patient were selected and grouped them into case \& control. 8gm Nalepsion (Magnesium sulphate heptahydrate) as a single I.V dose was selected for case and $10 \mathrm{gm} \mathrm{MgSO}_{4}(4 \mathrm{gm} \mathrm{I.V}+3 \mathrm{gm} \mathrm{I.M}$ in each buttock) was for control group. Different variables were compaired and results were analyzed by unpaired 't' test and chi-square test $\left(X_{2}\right)$ by SPSS programme.
\end{abstract}

Result: Statistically there was no significant difference of any finding between two groups after comparing all variables individually.

Conclusion: 8gm Nalepsin intravenously as a single loading dose is sufficient to control eclamptic convulsion and prevention of its recurrence.

\section{Introduction:}

Eclampsia, a life threatening complication of pregnancy, result when a pregnant women previously diagnosed with pre- eclampsia (high blood pressure and protein in urine) developed seizures or coma. ${ }^{1}$ In some cases, seizures or coma may be the first recognizable sign that a pregnant women has pre- eclampsia ${ }^{2}$. A sudden increase in blood pressure or occurrence of proteinuria may precipitate the disease in a patient of preeclampsia ${ }^{3}$. So, it is quite a preventable disease if adequate antenatal care is taken by the pregnant mother ${ }^{4}$. About $31 \%$ of pre- eclampsia are not preventable despite taking adequate prenatal care ${ }^{4,5}$.

Eclampsia accounts for approximately 50,000 maternal death world wide annually. ${ }^{6} \mathrm{It}$ is relatively uncommon in developed countries where it complicates about one in every 2000 deliveries $^{7}$. It is 20 times more common in developing countries and leading to $3^{\text {rd }}$ cause of maternal mortality in Bangladesh and account $16 \%$ of maternal death ${ }^{7,8,9}$. It is also a major cause of neonatal morbidity and mortality both directly and indirectly with intrauterine growth restriction and preterm delivery for abruption of placenta ${ }^{9,10}$. Death from eclampsia is difficult to prevent. So standard practice in eclampsia is urgent control of convulsion and prevention of its recurrence with the help of a suitable anti convulsion, prompt initiation of general and obstetrics management \& control of hypertension if needed. ${ }^{11,12}$ Among the many anticonvulsants, magnesium sulphate $\mathrm{MgSo}_{4}$ topped the list of all in terms of controlling convulsion \& improving other secondary outcome ${ }^{13}$. It is the abnormally low level of ionized magnesium in serum, which is responsible for eclamptic convulsion. ${ }^{6,14,15}$. In $\mathrm{DMCH}$, from begining magnesium sulphate $\left(\mathrm{MgSo}_{4}\right)$ being used as a routine anticonvulsant (The dose schedule is $4 \mathrm{~g}$ intravenous(IV) \& $3 g$ intramascular in

1. Assistant Prof. of Obstetrics \& Gynae, Dhaka Medical College Hospital

2. Ex. Prof \& Head of the Dept of Obstetrics \& Gynae, Dhaka Medical College Hospital

3. Assistant Prof. of Obstetrics \& Gynae, Dhaka Medical College Hospital

4. IMO, Dept of Obstetrics \& Gynae, Dhaka Medical College Hospital 
each buttock, a total of $10 \mathrm{~g}$ as a loading dose followed by $2.5 \mathrm{~g}$ I.M every 4 hours in alternate buttock until 24 hours after delivery or last fit). Now, only the loading dose of $\mathrm{MgSo}_{4}$ is being routinely used for controlling convulsion in eclampsia \& the dose is $4 \mathrm{~g}$ IV \& $3 \mathrm{~g}$ IM in each buttock (total $10 \mathrm{~g}$ ) for all patients. This study was planned to find out wheather $8 \mathrm{~g}$ Magnesium sulphate heptahydrate ( 2 bags of nalepsin) is sufficient to control convulsion \& to prevent recurrence in Bangladeshi women as they were lighter in their body weight. As the Bangladeshi women is light in their body weight this reduced dose appears to control convulsion effectively.

So, this small dose may control convulsion effectively \& to compare its efficacy with $10 \mathrm{~g} \mathrm{MgSo}_{4}$ (intravenous plus intramuscular) used as a loading dose. As Dhaka Medical College Hospital is a tertiary referral center and there is a separate eclampsia unit with improved facilities and intensive care, having a large number of critically ill patient and about 800-1100 were admitted in every year. So, $\mathrm{DMCH}$ was selected for this study. According to the hospital statistics in year 2002, admission of eclampsia patient were 865 and maternal mortality of this group was $38^{6}$. In subsequentyears upto 2006, statistical analysis shows death rate reduces not significantly. Lastly in 2007 , among 10,242 of total obstetric patient, eclampsia cases were 713 and death due to eclampsia was 34 (Total death of that year was 111), if $8 \mathrm{~g}$ magnesium sulphate heptahydrate $\left(\mathrm{MgSo}_{4}, 7 \mathrm{H}_{20}\right)$ is used, we can avoid painful intramascular injection, toxicity of drug also can be minimize, no need of calculating the dose \& administration is easy which require minimum medical personnel.

\section{Justification of the study}

The justification of this study is to reduce the eclampsia related maternal mortality by giving minimum dose of $\mathrm{MgSo}_{4}$ by prompt. I.V route without elapsing any time for calculating the dose and also to minimise the dose related side effect and toxicity as because the therapeutic and toxic dose of $\mathrm{MgSo}_{4}$ is very close. This method needs minimum man power to manage the case.

\section{Aim and Objective}

\section{Specific}

To find out whether only $8 \mathrm{~g}$ of magnesium sulphate as a single loading dose is sufficient to control eclamptic convulsion.

\section{General}

a) To compare the efficacy between $8 \mathrm{~g}$ and $10 \mathrm{~g}$ of $\mathrm{MgSO}_{4}$ used to control the convulsion.

b) To compare the recurrence of convulsion and other side effect between two groups.

c) To find out maternal and fetal outcome between two groups during study period.

\section{Material and Method}

\section{Study design}

Prospective randomized Case - Control study.

\section{Study Place}

Eclampsia unit, Department of Obstetrics and Gynaecology, Dhaka Medical College Hospital. Dhaka , Bangladesh.

\section{Study Period}

1 (one) year. From June '07 to May 08'

\section{Study Population}

Eclamptic patients fulfilling the criteria for study

\section{Inclusion Criteria}

Women with either ante partum or intrapartum eclampsia

\section{Exclusion Criteria}

- Eclampsia with severe complication, such as CVA, HELLP Syndrome, DIC, renal failure, pulmonary oedema \& shock. Women having known Medical diseases like diabetes mellitus, heart disease, Jaundice, blood dyscrasia etc.

- Contraindication of magnesium therapy (eg oligurea, renal failure, absent knee- jerk)

- Patient who received magnesium sulphate outside the hospital.

\section{Sample size}

100 case will be grouped by lottery into group A and group B.

a) Group -A : For $8 \mathrm{~g}$ of magnesium sulphate heptahydrate (Nalepsin)

intravenous (IV) route.

d) Group - B : For 10g magnesium sulphate, (4gm I.V slowly than $3 g$ I.M in each buttock) conventional treatment. 


\section{Methodology}

This study was conducted at DMCH for 1 (one) year from June 2007 to May 2008. Patient fulfilling the above mentioned criteria were selected for study and divided them randomely by lottery into two groups after taking detailed history from attendant, a preformed questionnaire was filled by investigator herself and a written consent for including them for study were taken. After thorough evaluation of cases, all necessary investigations like $\mathrm{CBC}$, estimation of total urinary protein, blood urea, serum creatinine, uric acid, FDP, fibrinogen level, serum electrolyte, platelate count, liver function test were done. But due to lack of facilities and inadequate funding serum magnesium level before and after the treatment with $\mathrm{MgSO}_{4}$ was not possible. Weight measuremt was not also possible due to convulsive state. So weight should be recorded from previous ANC record. Among two groups, the patients under group A were selected as a case and treated by $8 \mathrm{~g}$ of magnesium sulphate intravenously ( $4 \mathrm{~g} @$ of $70-75 \mathrm{~d} / \mathrm{m}$ and another $4 \mathrm{~g}$ ( $20-25 \mathrm{~d} / \mathrm{m}$ ) and group B were selected as a control $10 \mathrm{~g} \mathrm{MgSo}_{4-}$ as per schedule if their respiratory rate $>16 / \mathrm{min}$, urine output $>30 \mathrm{ml} /$ hour, knee jerk present. All patients were monitored hourly by pulse, $\mathrm{BP}$, respiratory rate, level of consciousness, knee jerk, auscultation of lungs, urine output with its colour, abnormal bleeding from any site. Continuous catheterization and I.V fluid was given very cautiously. Injection hydralazine $20 \mathrm{mg}$ in $200 \mathrm{ml}$ of $5 \%$ dextrose in aqua was given in continuous I.V drip when indicated for controlling of blood pressure. If recurrence of convulsion occur within 24 hours, then maintenance dose was given and if recurrence occur after 24 hours of initial dose than again loading dose was given with maintenance dose.

Complication if occurred any, such as HELLP syndrome, renal failure, cardiac arrest, pulmonary oedema were treated accordingly. After control of convulsion irrespective of gestational age, termination of pregnancy was done according to obstetric indication and Bishop scoring within limited time for eclamptic patient. Treatment was recorded in a clinical data sheet selected for case \& control group with proper \& systemic input; data was compiled, edited and analyzed by using SPSS programme. Because of the nature of analysis, chi- square $\left(X^{2}\right)$ test and unpaired ' $\mathrm{t}$ ' was performed and collected data were analyzed to decide upon the significance of finding. A 'P' value of $<0.05$ was considered as significant.

\section{Result:}

During study period from June 2007 to May 2008 total number of eclamptic patients were 710 (antepartum, intrapartum and postpartum). Among them, only 100 of the antepartum and intrapartum patient who fulfilled the inclusion criteria were including in this study. Different variable were studied between case and control group and results were analyzed by unpaired ' $t$ ' test and chi-square test $\left(X^{2}\right)$.

The number of patient in group $A=48$ and group $B=52$

The result of different parameters of patient profile of both group such as age, gravidity, socioeconomic condition, status of antenatal care, gestational age, type of eclampsia were found not significant statistically.

All parameters of this study shown below.

Table-I

Age distribution

\begin{tabular}{lccl}
\hline Age (Years) & $\begin{array}{c}\text { Control (n-52) } \\
\text { No. (\%) }\end{array}$ & $\begin{array}{c}\text { Case (n-48) } \\
\text { No. (\%) }\end{array}$ & P value \\
\hline$\leq 20$ & $22(42.3)$ & $19(39.6)$ & $>0.50^{\text {ns }}$ \\
$>20$ & $30(57.7)$ & $29(60.4)$ & \\
(Meant \pm SD) & $22.44 \pm 4.11$ & $22.92 \pm 3.83$ & $>0.50^{\text {ns }}$ \\
Range & $18-35$ & $18-36$ & \\
\hline
\end{tabular}

Table - I Shows age distribution of case \& control group \& result is statistically not significant.

Chi- square / unpaired Student's 't' test

ns= Not significant.

Table-II

Socioeconomic status

\begin{tabular}{lccl}
\hline Status & $\begin{array}{c}\text { Control (n-52) } \\
\text { No. (\%) }\end{array}$ & $\begin{array}{c}\text { Case (n-48) } \\
\text { No. (\%) }\end{array}$ & P value \\
\hline Low & $45(86.5)$ & $34(70.8)$ & $>0.05^{\text {ns }}$ \\
Middle & $7(13.5)$ & $14(29.2)$ & \\
\hline
\end{tabular}

Table-II Shows the socioeconomic status of both group $\&$ result shows no statistical significance between two group.

Chi- square test

ns $=$ Not significant. 
Table-III

Gravidity of the patients.

\begin{tabular}{lccl}
\hline Gravidity & Control (n-52) & Case (n-48) & P value \\
& No. (\%) & No. (\%) & \\
\hline Primi & $37(71.2)$ & $36(75.0)$ & \\
Multi & $12(23.1)$ & $10(20.8)$ & $>0.50^{\text {ns }}$ \\
Grandmulti & $3(5.8)$ & $2(4.2)$ & \\
\hline
\end{tabular}

Table-III Shows gravidity between case \& control group \& shows no significance between two group statistically. Chi- square test ns= Not significant.

Table-IV

Status of antenatal care

\begin{tabular}{lccl}
\hline ANC & Control $(n-52)$ & Case (n-48) & P value \\
& No. $(\%)$ & No. (\%) & \\
\hline Regular & $11(21.2)$ & $13(27.1)$ & \\
Irregular & $20(38.5)$ & $19(39.5)$ & $>0.50^{\text {ns }}$ \\
None & $21(40.0)$ & $16(33.3)$ & \\
\hline
\end{tabular}

Table-IV Shows status of antenatal care in two group \& statistical analysis of result proves no significance between two group

Chi- square test ns $=$ Not significant.

Table-V Gestational age

\begin{tabular}{lccc}
\hline $\begin{array}{l}\text { Gestational } \\
\text { (weeks) }\end{array}$ & $\begin{array}{c}\text { Control (n-52) } \\
\text { No. (\%) }\end{array}$ & $\begin{array}{c}\text { Case (n-48) } \\
\text { No. (\%) }\end{array}$ & P value \\
\hline$\leq 32$ & $14(26.9)$ & $14(29.2)$ & \\
$33-36$ & $17(32.7)$ & $22(45.8)$ & $>0.10^{\text {ns }}$ \\
$\geq 37$ & $21(40.0)$ & $12(25.0)$ & \\
\hline
\end{tabular}

Table- V. Shows gestational age of the patient between two group on admission \& result is statistically not significant.

Chi- square / unpaired Student's 't' test ns= Not significant.

Table-VI

Type of eclampsia

\begin{tabular}{lccc}
\hline Type & $\begin{array}{c}\text { Control (n-52) } \\
\text { No. (\%) }\end{array}$ & $\begin{array}{c}\text { Case (n-48) } \\
\text { No. (\%) }\end{array}$ & P value \\
\hline Antepartum & $43(83.7)$ & $34(70.8)$ & \\
& & & $>0.10^{\text {ns }}$ \\
Intrapartum & $9(17.3)$ & $14(29.2)$ & \\
\hline
\end{tabular}

Table-VI Shows type of eclampsia of both groups \& after statistical analysis, shows not significant between two groups.

Chi- square test

ns= Not significant.
Table-VII

Number of convulsion before hospital admission

\begin{tabular}{lccl}
\hline $\begin{array}{l}\text { Number of } \\
\text { convulsion }\end{array}$ & $\begin{array}{c}\text { Control (n-52) } \\
\text { No. (\%) }\end{array}$ & $\begin{array}{c}\text { Case (n-48) } \\
\text { No. (\%) }\end{array}$ & P value \\
\hline $1-2$ & $11(21.2)$ & $15(31.3)$ & \\
$3-5$ & $25(48.1)$ & $17(35.4)$ & $>0.10^{\text {ns }}$ \\
$>5$ & $16(30)$ & $16(33.3)$ & \\
\hline
\end{tabular}

Table -VII display the number of convulsion before hospital admission and after statistical analysis of both group by chi-square test, result shows no significance difference between two groups.

Table-VIII

Recurrence of convulsion after initiation of treatment.

\begin{tabular}{lccl}
\hline Recurrence & $\begin{array}{c}\text { Control (n-52) } \\
\text { No. }(\%)\end{array}$ & $\begin{array}{c}\text { Case (n-48) } \\
\text { No. (\%) }\end{array}$ & P value \\
\hline Yes & $9(17.3)$ & $6(12.5)$ & $>0.50^{\text {ns }}$ \\
No & $43(82.7)$ & $42(87.5)$ & \\
\hline
\end{tabular}

This table also shows no significant result after analysis by chi-square test.

Table IX

Level of consciousness on admission to the Hospital.

\begin{tabular}{lccl}
\hline $\begin{array}{l}\text { Level of } \\
\text { consciousness }\end{array}$ & No. (\%) & No. (\%) & \\
\hline Conscious & $30(57.7)$ & $25(52.1)$ & \\
Unconscious & $9(17.3)$ & $14(29.2)$ & $>0.10$ ns \\
Semi conscious & $13(25.0)$ & $9(18.8)$ & \\
\hline
\end{tabular}

Table of this parameter of both group after analysis by chi-square test shows not significant.

Table X

Time required to regain consciousness after initiation of treatment.

\begin{tabular}{lccl}
\hline $\begin{array}{l}\text { Time } \\
\text { (Hours) }\end{array}$ & $\begin{array}{c}\text { Control } n-22 \\
\text { No(\%) }\end{array}$ & $\begin{array}{c}\text { Case }(\mathrm{n}-23) \\
\mathrm{No}(\%)\end{array}$ & P value \\
\hline$<4$ & $11(50.0)$ & $12(52.2)$ & \\
$4-24$ & $8(36.4)$ & $12(30.4)$ & $>0.50 \mathrm{~ns}$ \\
$>24$ & $3(13.6)$ & $4(17.4)$ & \\
\hline
\end{tabular}

This table shows time required to regain consciousness after initiation of treatment and result shows not significant statistically after analysis by chisquare test. 
Table-XI

Status of blood pressure on admission and at discharge from Hospital.

\begin{tabular}{lccc}
\hline Blood Pressure $(\mathrm{mm}$ of Hg) & Control $($ Meant \pm SD) & Case (Meant \pm SD) & P value \\
\hline SBPOn Admission & $148.56 \pm 21.24(\mathrm{n}-52)$ & $152.92 \pm 23.58(\mathrm{n}-48)$ & $>0.10^{\mathrm{ns}}$ \\
At discharge & $123.47 \pm 13.35(\mathrm{n}=49)$ & $124.67 \pm 11.66(\mathrm{n}=46)$ & $>0.50^{\mathrm{ns}}$ \\
DBPOn Admission & $104.12 \pm 16.97(\mathrm{n}=52)$ & $102.29 \pm 12.84(\mathrm{n}=48)$ & \\
\hline
\end{tabular}

Table-XI. States of blood pressure on admission and at discharge between two group \& result is not significant statistically.

Unpaired Student's 't' test and Chi- square test

ns= Not significant.

Table XII

Maternal complication

\begin{tabular}{lccc}
\hline Complication & $\begin{array}{c}\text { Control (n-52) } \\
\text { No. }(\%)\end{array}$ & $\begin{array}{c}\text { Case (n-48) } \\
\text { No. }(\%)\end{array}$ & \\
\hline Present value & \\
Absent & $6(11.5)$ & $4(8.3)$ & $>0.05^{\text {ns }}$ \\
Type of complication & $46(88.5)$ & $44(91.7)$ & \\
Pulmonary oedema & $2(33.3)$ & & \\
Renal Failure & $2(33.3)$ & $1(25.0)$ & \\
PPH & $2(33.2)$ & $2(50.0)$ & \\
\hline
\end{tabular}

Table - XII Shows maternal complications of both group and after statistical analysis result shows no significant different between two groups.

Chi- square test

ns $=$ Not significant.

\section{Discussion:}

Eclampsia is one of the main cause of maternal mortality in developing country. It is a very serious \& relatively frequent life threatening obstetrics emergency. In developing country like Bangladesh among other causes of maternal death eclampsia account one third. ${ }^{7,1617}$ Magnesium level $<0.7 \mathrm{mmol} /$ $L$ indicative of magnesium deficiency . Symptoms appears when level fall $<.5 \mathrm{mmol} / \mathrm{L}$ Magnesium has independent attributes in cellular function. This low $\mathrm{Mg}^{+2}$ level causes disruption of cellular function ${ }^{6}$. Magnesium sulphate $\left(\mathrm{MgSo}_{4}\right)$ which is the most commonly used medication for the treatment \& prevention of convulsion in patient with severe preeclampsia \& eclampsia as because it is superior to all other anticonvulsant in term of controlling \& preventing convulsion ${ }^{18}$. Its efficacy for preventing a second convulsion in eclampsia has been proven conclusively by prospective randomized trails $\&$ its prophylactic role is currently being assured
Table-XIII

Maternal death \& cause of death

\begin{tabular}{lcll}
\hline Death & $\begin{array}{c}\text { Control (n-52) } \\
\text { No. (\%) }\end{array}$ & $\begin{array}{c}\text { Case (n-48) } \\
\text { No. (\%) }\end{array}$ & \\
\hline Yes & $3(5.8)$ & $2(4.2)$ & $>0.05^{\text {ns }}$ \\
No & $49(94.2)$ & $46(95.8)$ & \\
Cause of death & & & \\
Respiratory Failure1 (33.3) & $1(50.0)$ & \\
Renal Failure & $2(66.7)$ & $1(50.0)$ & \\
\hline
\end{tabular}

Table.XIII Shows number of maternal death and their causes, after analysis of the result it shows no significance difference

chi-square test.

ns= Not significant.

prospectively in several studies, ${ }^{19}$. Use of magnesium sulphate has been found to be associated with significant reduction of maternal mortality primarily by its action on reliving cerebral vasospasm ${ }^{20,21}$.

This prospective case control study was designed to find out the lowest single dose of $\mathrm{MgSo}_{4}$ which effectively control the eclamptic seizures $\&$ also prevent the recurrence of convulsion. The idea for this lowest dose is, as because the Bangladeshi women are lighter in their body weight which may reduce the $\mathrm{MgSo}_{4}$ related toxicities. By this study we also compare the treatment outcome with the existing regimen of $\mathrm{MgSO}_{4} 4 \mathrm{gm} \mathrm{I.V} \mathrm{(over} 15$ minute along with $3 \mathrm{gm}$ in each buttock intramuscularly as a loading dose. There was another study done by (Dr. Nilufar et al' 2003) they proved that only $10 \mathrm{gm}$ loading dose of magnesium sulphate was sufficient to control convulsion in eclamptic patient \& also to prevent recurrence with the previous regimen ( $4 \mathrm{gm} \mathrm{I.V+6gm}$ I. $\mathrm{m}+2.5 \mathrm{gm}$ I.m 4 hours for 24 hour). By this study we 
also proved $8 \mathrm{gm}$ of $\mathrm{MgSO}_{4}$ if given intravenously in a single dose is sufficient to control eclamptic convulsion which is not statistically significant with the $10 \mathrm{gm}$ used for control group. Though there was some limitations even than we found that fetal hypotonia \& neonatal hypermagnesemia also reduced due to minimum dose.

\section{Limitation of the study}

1. Different type of essential investigation were difficult to do in emergency basis due to lack of facilities and as well as lack of ability of the patient.

2. This study confined to a limited number of patient was probably statistically not much significant and too difficult to find out the exact epidemiological importance.

3. Most of the patient was unable to respond to the questionnaire. The attendant in many instances were helpful, but were less informative. So they were also unable to answer correctly to the questionnaires.

\section{Conclusion}

As because the Bangladeshi women were lighter in their body weight \& if any pregnant patient developed eclampsia and fulfilling the inclusion criteria only $8 \mathrm{gm}$ $\mathrm{MgSo}_{4}$ heptahydrate (2bags Nalepsin) can be used effectively to control convulsion in eclamptic patient and it is also cost effective and easy to use.

\section{Recommendation}

Unless any serious complication occured with eclamptic patient it is the $8 \mathrm{gm}$ of $\mathrm{MgSo}_{4}$ heptahydrate which is sufficient to control the convulsion in eclamptic patient. It also minimize the dose related toxicity and mode of administration is easy and avoid intramascular painful injection. But further study with a big series is needed.

\section{References}

1. Sibai BM, Abdella TN, Spinnato JA. Eclampsia .IV. The incidence of non preventable eclampsia . Am J obstet Gynaecol 1986; 154:581 -6

2. Bangladesh bureau of statistics 2002.

3. Begum MR, Begum A, Quadir E, et al. Eclampsia still a problem in Bangladesh.

4. Rabya Akhter, is low level of Serum ionized magnesium responsible for Eclampsia.
Dissertation, Bangladesh College of Physician and Surgeon 2004.

5. Rouf $S$ clinical profile \& management of eclampsia, patient admitted in $\mathrm{DMCH}$ by a new protocol, Dissertation, Bangladesh College of Physician \& Surgeons, 1993;5-6.

10. Harison principle of medicine, $15^{\text {th }}$ edition 1998.

11. Bangladesh Economic Review 2006.

12. Khatun $\mathrm{S}$, Nilufar $\mathrm{S}$, Bhuiyan $\mathrm{AB}$, Begum $\mathrm{K}$, Perinatal outcome in Eclampia in Bangladesg J, Obstetrics and Gynaecology 1994:9,53-60.

13. New England journal of medicine; vol 310; No 19,1253 -54,1984.

14. Yamolle NR, Eclampsia : a taxing situation in the third world.International Gynaecol \&

obstet 1917;58:311-12.

15. Cunze $\mathrm{T}$ et al. Magnesium and calcium concentration in pregnant and non pregnant myometrium I nt. J Obstet Gynaecol 1995; 48:913.

16. Dr. Monia Ahmed Estimation of serum magnesium level in eclamptic women \& fetal cord blood before \& after giving magnesium sulphate Disseratation BCPS library 2002.

17. Sibai BM, Eclampsia VI, maternal \& perinatal out come in 54 consecution cases Am J Obstet Gynaecol, 1990;163:1049-54.

18. The Eclampsia Trial Collaborative Group which anticonvulsant for women with eclampsia, Evidence from the collaborative eclampsia trial. Lancet 1995;345:1455-1463.

19. Compbell $S$ and less $C$ (editors) Disorders of placentation in : Obstetrics by ten teachers. $17^{\text {th }}$ edition chapter 11 London, FLST with Amold 2000:157-166.

20. Begum R, Begum A, Bullough Ch, Johanson RB. Reducing maternal mortality from eclampsia using magnesium sulphate Eur J Obstet Gynaecology Reprod. Biol. 2000

October, 92(2): 223-4.

21. Naidu S. payne A.V Moodley J. Hoffman M-E. Randomized study assessing the effects of phemytrin \& magnesium sulphate on maternal cerebral circulation in eclampsia using transcervical Doppler ultrasound $\mathrm{Br}$ J. Obstal Gynaecology 1996;103:11-6. 